\title{
Off-label prescriptions in diabetic foot
}

\author{
Prescrições off-label em pé diabético \\ Luís Jesuíno de Oliveira Andrade ${ }^{1,2}$, Larissa Santos França33, Paulo Roberto Santana de Melo ${ }^{1,4}$, Marcelo Araújo
}

\begin{abstract}
Prescription of a drug outside of the indications for which it was originally approved by regulators is internationally known as "off-label" prescription. We describe off-label treatments for the diabetic foot reported in international scientific literature. This is a qualitative and descriptive bibliographical review based on the results of a search of the Medline international database. The criteria for review were publication between January 1985 and November 2013, and the MeSH (Medical Subject Heading) keywords "off-label use" OR "off-label" OR "off-label prescribing" plus "diabetic foot" were input on the search form. Nine studies were selected that contained information about off-label treatments for the diabetic foot. We conclude that the practice of off-label prescribing has potential benefits. In some situations an off-label prescription is the only treatment available for patients, either because a more targeted drug does not exist, or because other methods of treatment are ineffective or unavailable due to patient intolerance.
\end{abstract}

Keywords: off-label use; diabetic foot; diabetes mellitus.

\begin{abstract}
Resumo
A prescrição de um medicamento sem as indicações para as quais a droga foi originalmente aprovada por órgãos reguladores é internacionalmente conhecida como prescrição off-label. Descrevemos a terapia off-label em pé diabético, relatada na literatura científica internacional, por meio de uma revisão bibliográfica qualitativa, descritiva, através de pesquisa na base de dados internacional Medline, para seleção dos artigos. Os critérios para revisão foram publicações entre janeiro de 1985 e novembro de 2013, sendo as palavras-chave MeSH "off-label use" OR "off-label" OR "off-label prescribing" plus "diabetic foot" - colocadas no formulário de busca. Foram selecionados nove artigos com informações sobre a terapia off-label em pé diabético. Conclui-se que a prática de prescrição off-label possui benefícios potenciais em muitas situações. Em algumas circunstâncias, uma prescrição off-label é o único tratamento disponível, seja por não existir uma droga específica, seja porque outros métodos de tratamento são ineficazes ou não disponíveis por intolerância.
\end{abstract}

Palavras-chave: uso off-label; pé diabético; diabetes mellitus. 


\section{INTRODUCTION}

Many medications are prescribed for uses that are not included in their conditions of approval for sale (off-label) granted by the organ responsible for regulating the health sector in a given country. In the case of Brazil, the responsible authority is the National Agency for Sanitary Vigilance (ANVISA - Agência Nacional de Vigilância Sanitária). Offlabel use of medications is very common in medical practice, even in the absence of strong scientific evidence. Off-label prescribing is defined as when medications are used for indications that are not mentioned on their information leaflets, in other words, prescribing a drug for a disease or patient, or using a route of administration or dosage, that have not been approved by the country's healthcare agency. This type of prescription is legal, but healthcare regulatory organizations determine certain rules for prescribers. Several different studies have demonstrated that off-label prescribing is a common practice in medicine, showing that around $20 \%$ of prescriptions are made off-label annually. ${ }^{1,2}$ The value of understanding this subject is incalculable, in order to provide information on which to base and improve conditions of use.

The range of off-label usage takes in the practice of recommended guidance, last resort treatments and first-line therapy. This type of prescribing offers an alternative option in clinical practice, especially when approved treatments fail, and makes it possible to adopt new practices based on emerging evidence. The pharmaceutical industry has facilitated offlabel usage, exploiting areas of ambiguity in which policies are permissive, undefined or inapplicable. Off-label prescribing can be classified into three major categories as follows: off-label usage that is justifiable on the basis of high-quality evidence; off-label usage as part of a formal research project; and exceptional usage, justifiable on the basis of individual clinical circumstances. ${ }^{3}$

These prescriptions are used in all medical specialties, but they can be more common in areas of medicine that deal with populations of patients who are less likely to be enrolled in clinical trials, such as, for example, children, expectant mothers and psychiatric patients. ${ }^{4}$ In endocrinology, off-label usage of drugs can be considered appropriate on the basis of knowledge of clinical pharmacology, of results of clinical studies and, sometimes, based on the personal experience of the prescriber. However, before recommending or prescribing any type of therapeutic agent off-label, physicians must ensure they are fully aware of the complete drug information, including indications, contraindications, warnings, precautions and adverse events.

In some countries there are some guidelines related to prevention and clinical treatment of the diabetic foot. However, differences between the specialties involved and objectives or patient characteristics led to different guidelines recommending different approaches. There is a clear need for an international consensus that could become the starting point for formulation of guidelines for individual countries. In this article we present a qualitative and descriptive review of studies available in the medical literature covering the current extent of off-label prescribing for patients with diabetic feet.

\section{METHODOLOGY}

\section{Definition of sample}

An integrative literature review was conducted starting from the results of a search run on the Medline international database of articles. One of the descriptor fields on the Medline search form is for MeSH (Medical Subject Heading) terms and can be used to produce specific results listing articles that utilize those keywords.

The following inclusion criteria were defined for the review: articles published from January 1985 to July 2013; using the MeSH keywords "off-label use" or "off-label" or "off-label prescribing"; plus the term "diabetic foot"; and articles that had an abstract in English available. The articles returned by the search were evaluated in predefined categories, such as impact factor and subject discussed. Once these manuscripts had been chosen, the articles were read analytically and the articles were organized by subject.

\section{RESULTS}

A total of 852 articles were identified and nine of these studies were selected for review having been found to meet the criteria on off-label treatment of the diabetic foot.

Five major types of off-label prescription were used for treatment of the diabetic foot: antibiotics; biological dressings; hyperbaric oxygen therapy; vasodilators; and hemorheologic agents, each of which will be described in this paper (Table 1). 
Table 1. Off-label treatment of the diabetic foot (references).

\begin{tabular}{lcc}
\hline & Topical & Systemic \\
\hline Antibiotics & Griffis et al. ${ }^{5}$ Nelson et al. ${ }^{6}$ Lipsky et al. ${ }^{7}$ & Cavanagh et al. $^{8}$ \\
Hyperbaric oxygen & Lo Pardo et al. ${ }^{9}$ & \\
Biological dressings & Holmes et al. ${ }^{10}$ & Papanas et al. $^{11}$ \\
Vasodilators & & ${\text { Solerte et al. }{ }^{12} \text { Cicco et al. }{ }^{13}}_{\text {Hemorheologic agents }}$ \\
\hline
\end{tabular}

\section{DISCUSSION}

The literature on off-label usage describes benefits that are based on standards of best medical practices, in view of the fact that the regulatory agencies are slow to approve drugs. ${ }^{14,15}$ There is also the issue of orphan diseases, such as the diabetic foot, in which the pharmaceutical industry invests little in the clinical trials needed for approval. ${ }^{2,16,17}$

Medical associations tend to accept off-label usage of certain drugs for treatment of the diabetic foot, including them in protocols and guidelines, and there is consensus among specialists for cases when on-label treatment options have been exhausted.

In Brazil, ANVISA resolution RDC n ${ }^{\circ} 47$ (passed on 8 September 2009) states that the drug information leaflet is the legal sanitary document providing technical and scientific guidance on medications for their rational use. ${ }^{18}$ Therefore, the responsibility for off-label usage of a medication for a given condition falls to the prescribing physician and patients must be made aware of any differences from the indications provided in the documentation registered with ANVISA.

Treatment of diabetic foot ulcers is to a great extent dependent on the subjacent cause, such as ischemia, neuropathy or a combination of the two. In view of the complexity of this clinical condition, treatment by a specialized multidisciplinary team is recommended. Several institutions do not recommend any type of off-label diagnostic or pharmacological test or medication for treatment of the diabetic foot. Notwithstanding, many medications are employed off-label for treatment of the diabetic foot, as will be described below.

\section{Antibiotics}

There is no data to support antibiotic treatment of chronic ulcers, even with a positive culture result. The ischemia and leukocyte dysfunction seen in diabetics result in poor response to treatment of infections and can even worsen the condition rapidly. However, the functional defects in diabetic patients' neutrophils mean it is advisable to administer bactericidal antibiotics for prolonged periods, while the ischemia demands elevated dosages. ${ }^{19}$ The wound infection should be treated, circulatory abnormalities should be improved and the healing process should be promoted by localized measures, such as debridement of wounds and dressings.

The two most common types of diabetic foot are chronic wounds and "Charcot foot". The diabetic foot is a devastating complication, although potentially avoidable, and its result is the sobering statistic that every 30 seconds a lower limb is lost to diabetesrelated amputation somewhere in the world. ${ }^{2}$ Ulcers of the diabetic foot are often complicated by infection because of the elevated bacterial load. Antimicrobial therapy is an important component in management of these wounds, but, for treatment to be effective, adequate concentrations of the antimicrobial agent are mandatory. Drug concentrations in the interstitial space are an important determinant of successful treatment. In vitro, gentamicin sulphate has demonstrated activity against many strains of Gram-negative and Gram-positive pathogens, but it is often rejected as a treatment option because of the risk of toxicity associated with parenteral use. Incorporation of antimicrobial agents into collagen implants can limit this risk, providing a controlled dose of the drug at the target site. This reduced risk in combination with the fact that the implant is biocompatible and does not need to be removed means that antibiotic collagen implants are superior for off-label treatment of the diabetic foot. ${ }^{5}$

Although antibiotics such as such as neomycin, polymyxin, gentamicin and mupirocin have been used topically off-label, there are no good-quality studies that have shown using these antibiotics topically to be favorable, either in terms of curing wounds or of reducing the number of amputations. ${ }^{6}$

Antibiotics are often used off-label and can change the underlying microbiological parameters obtained thereafter. However, off-label treatment is based both on the severity of the infected wound and also on epidemiological data. The systemic antibiotics 
most often employed off-label for treatment of the diabetic foot are the aminoglycosides, vancomycin, the quinolones and amphotericin B. ${ }^{8}$

A recent study to assess the safety and benefits of a collagen sponge with topical gentamicin for treatment of moderate severity infections of the diabetic foot showed that the procedure was safe and had the potential to improve clinical and microbiological results when combined with the standard treatment. ${ }^{7}$

\section{Biological tissue dressings}

The infected diabetic foot can be complicated by infection of the fascial compartment, which is a condition requiring surgical drainage. Elective amputation can be considered for patients with recurrent ulcers, irreversible loss of function or lesions that require long-term hospital treatment. If an infected diabetic foot has ischemia, it will need revascularization. The result of revascularization is related to the extent of the involved artery. Debridement removes bacterial colonies, promotes granulation tissue and reepithelialization and also facilitates collection of samples for microbiological analyses. Hyperbaric oxygen therapy for treatment of the infected diabetic foot is controversial, because there are few studies of the technique and those that do exist employed questionable methodology. Findings related to use of growth factors and biological dressings are similar. ${ }^{9}$

Several different studies have described using biological tissues, obtained using bioengineering, with cultured keratinocytes seeded onto a structure populated with fibroblasts synthesized from bovine collagen, or by superimposing diploid human fibroblast cells onto a three-dimensional polymer of matrix proteins, cultured from neonatal foreskin.

Wounds have also been treated using acellular dermal tissues obtained from human tissues from which living tissue is removed but the matrix is left intact to serve as a medium for revascularization and transplantation into the host. Dressings using collagen xenografts consisting of an extracellular collagen matrix derived from the submucosa of porcine small intestine have also been used off-label for treatment of the diabetic foot. Other types of collagen matrix based dressings include collagen with silver, collagen with alginate, collagen with protease inhibitors, collagen gel, bone marrow impregnated with collagen matrix and dressings with amniotic membrane, all used as off-label treatments. ${ }^{10}$

\section{Vasodilators and hemorheologic agents}

In diabetic patients, microcirculatory dysfunction can contribute to secondary complications of the extremities of the lower limb, including diabetic foot. The combination of dysfunctional vascular endothelial cells and vascular smooth muscle cells reduces observed vasodilation in diabetic patients and this is the main reason why healing of the diabetic foot is so problematic.

Vasodilatory agents can substantially improve neuronal blood flow, with a corresponding improvement in velocity of nerve conduction. Therefore, the microvascular dysfunction that is seen in diabetics, concurrently with neural dysfunction, may be sufficient to explain the severity of the structural, functional and clinical changes observed in the diabetic foot. Therefore, cilostazol, which is a phosphodiesterase III inhibitor, has become the drug of choice for off-label treatment of the diabetic foot. ${ }^{11}$

The rheological properties of the blood play an important role in regulation of blood flow resistance and data show that these characteristics are impaired in diabetes. The reduction in the red blood cells' deformation capacity, the increase in aggregability, the vasoconstriction, the increase in blood viscosity and the reduced oxygen supply all have significant effects on wound healing, as is the case with the diabetic foot.

Abnormalities of blood rheology have often been described in diabetic patients and can be associated with increased risk of diabetic foot. For such situations, it has been suggested that a hemorheologic approach to management of patients with diabetic foot be taken, using pentoxifylline, in order to improve the hemorheologic profile and to evaluate the long-term effects of this treatment on other clinical and metabolic variables. Studies have demonstrated that pentoxifylline significantly reduces blood and plasma viscosity, fibrinogen and erythrocytes aggregation, and facilitates erythrocyte filtration. These improvements in hemorheologic parameters were obtained irrespective of variations in glycometabolic state and body weight. Pentoxifylline has been successfully employed for long-term hemorheologic management of diabetic patients, without impacting on metabolic parameters. $^{12}$

Pentoxifylline is defined as a hemorheologic agent that improves red blood cell deformation and has been used in treatment of peripheral vascular disease 
to improve distal blood flow. It has been reported that high-dose, long-term, off-label use of pentoxifylline is useful for treatment of the diabetic foot. ${ }^{13}$

\section{FINAL COMMENTS}

This article presented a qualitative and descriptive review of off-label treatment of the diabetic foot.

The current system allows for drugs that are safe and effective for one indication to be used for any other indication without adequate safeguards. Furthermore, an off-label prescription must not be converted into an experimental study or investigation, but, on many occasions, the possibility of off-label prescription has proved essential for successful treatment of certain very serious diseases. Therefore, off-label use of drugs is just one element in the wider issue of how to balance benefits, harm and costs of medical interventions, when technological advances are rapid, evidence is imperfect and resources are finite.

It can thus be concluded that off-label use of medications for patients with diabetic foot is one possible option for treatment of this complication of diabetes and its use has demonstrated improvements in signs and symptoms, while specific medications are not yet approved for on-label use.

\section{REFERENCES}

1. Emmerich J, Dumarcet N, Lorence A. France's new framework for regulating off-label drug use. N Engl J Med. 2012;367(14):1279-81. http://dx.doi.org/10.1056/NEJMp1208347. PMid:23034018

2. Stafford RS. Regulating off-label drug use-rethinking the role of the FDA. N Engl J Med. 2008;358(14):1427-9. http://dx.doi. org/10.1056/NEJMp0802107. PMid:18385495

3. Gazarian M, Kelly M, McPhee JR, Graudins LV, Ward RL, Campbell TJ. Off-label use of medicines: consensus recommendations for evaluating appropriateness. Med J Aust. 2006;185(10):544-8. PMid:17115966.

4. Wittich CM, Burkle CM, Lanier WL. Ten common questions (and their answers) about off-label drug use. Mayo Clin Proc. 2012;87(10):982-90. http://dx.doi.org/10.1016/j. mayocp.2012.04.017. PMid:22877654

5. Griffis CD, Metcalfe S, Bowling FL, Boulton AJ, Armstrong DG. The use of gentamycin-impregnated foam in the management of diabetic foot infections: a promising delivery system? Expert Opin Drug Deliv. 2009;6(6):639-42. http://dx.doi. org/10.1517/17425240902997919. PMid:19519289

6. Nelson EA, O'Meara S, Golder S, Dalton J, Craig D, Iglesias $C$, and the DASIDU Steering Group. Systematic review of antimicrobial treatments for diabetic foot ulcers. Diabet Med. 2006;23(4):348-59. http://dx.doi.org/10.1111/j.14645491.2006.01785.x. PMid:16620262

7. Lipsky BA, Kuss M, Edmonds M, Reyzelman A, Sigal F. Topical application of a gentamicin-collagen sponge combined with systemic antibiotic therapy for the treatment of diabetic foot infections of moderate severity: a randomized, controlled, multicenter clinical trial. J Am Podiatr Med Assoc. 2012;102(3):223-32. http://dx.doi.org/10.7547/1020223. PMid:22659765

8. Cavanagh PR, Lipsky BA, Bradbury AW, Botek G. Treatment for diabetic foot ulcers. Lancet. 2005;366(9498):1725-35. http:// dx.doi.org/10.1016/S0140-6736(05)67699-4. PMid:16291067

9. Lo Pardo D, Pezzuti G, Selleri C, Pepe S, Esposito S. [Adjuvant treatment of diabetic foot]. Infez Med. 2012;20(Suppl 1):35-41. PMid:22982696.

10. Holmes C, Wrobel JS, Maceachern MP, Boles BR. Collagenbased wound dressings for the treatment of diabetes-related foot ulcers: a systematic review. Diabetes Metab Syndr Obes. 2013;6:17-29. http://dx.doi.org/10.2147/DMSO.S36024. PMid:23357897

11. Papanas N, Maltezos E. Cilostazol in diabetic neuropathy: premature farewell or new beginning? Angiology. 2011;62(8):6058. http://dx.doi.org/10.1177/0003319711402664. PMid:21511679

12. Solerte SB, Fioravanti M, Cerutti N, et al. Retrospective analysis of long-term hemorheologic effects of pentoxifylline in diabetic patients with angiopathic complications. Acta Diabetol. 1997;34(2):67-74. http://dx.doi.org/10.1007/s005920050069. PMid:9325467

13. Cicco G, Giorgino F, Cicco S. Wound healing in diabetes: hemorheological and microcirculatory aspects. Adv Exp Med Biol. 2011;701:263-9. http://dx.doi.org/10.1007/978-1-4419-77564 35. PMid:21445796

14. Baldwin DS, Kosky N. Off-label prescribing in psychiatric practice Adv Psychiatr Treat. 2007;13(6):414-22. http://dx.doi.org/10.1192/ apt.bp.107.004184.

15. Lowe-Ponsford FL, Baldwin DS. Off-label prescribing by psychiatrists. Psychiatr Bull. 2000;24(11):415-7. http://dx.doi. org/10.1192/pb.24.11.415.

16. Gazarian M, Kelly M, McPhee JR, Graudins LV, Ward RL, Campbel TJ. Off-label use of medicines: consensus recommendations for evaluating appropriateness. Med J Aust. 2006;185(10):544-8. PMid:17115966.

17. Radley DC, Finkelstein SN, Stafford RS. Off-label prescribing among office-based physicians. Arch Intern Med. 2006;166(9):1021-6. http://dx.doi.org/10.1001/archinte.166.9.1021. PMid:16682577

18. Brasil. Ministério da Sáude. Agênica Nacional de Vigilância Sanitária - ANVISA. Resolução RDC n 47, de 08 de setembro de 2009. Diário Oficial da República Federativa do Brasil, Brasília 09 set. 2009. Seção 1. p. 31. [citado 2014 fev. 2014]. http://www. anvisa.gov.br/medicamentos/bulas/rdc_47.pdf

19. Blanes JI, Representatives of Spanish Society of Surgeons (ACS), Representatives of Spanish Society of Angiology and Vascular Surgery (SEACV), Representatives of Spanish Society of Emergency Medicine (SEMES), Spanish Internal Medicine Society (SEMI), Representatives of Spanish Society of Critical Care Medicine and Coronary Units (SEMICYUC), Representatives of Spanish Society of Chemotherapy (SEQ). Consensus document on treatment of infections in diabetic foot. Rev Esp Quimioter. 2011;24(4):233-62. PMid:22173195.

20. Boulton AJ, Vileikyte L, Ragnarson-Tennvall G, Apelqvist J. The global burden of diabetic foot disease. Lancet. 2005;366(9498):1719-24. http://dx.doi.org/10.1016/S0140 6736(05)67698-2. PMid:16291066 
Correspondence Luís Jesuíno de Oliveira Andrade Rua Nações Unidas, 511 - Centro CEP 45600-670 - Itabuna (BA), Brasil Fone: +55 (73) 3212-1511

E-mail: luis_jesuino@yahoo.com.br

Author information

LJOA is an MSc and PhD in Medicine and Health from Universidade Federal da Bahia; an adjunct professor at the School of Medicine of Universidade Estadual de Santa Cruz; and an Endocrinologist at

Santa Casa de Itabuna.

LSF is a medical doctor from Faculdade de Tecnologia e Ciências. PRSM is an MSc and PhD in Human Pathology from UFBAFIOCRUZ; a $\mathrm{PhD}$ (sandwich program) from Case Western Reserve University, Ohio, USA; and an Adjunct Professor at Universidade Estadual de Santa Cruz. MA is an MSc in Surgical Techniques and Experimental Surgery

from Universidade Federal de São Paulo; a PhD in Medicine (Cardiovascular Surgery) from Universidade Federal de São Paulo; an Assistant Professor at Universidade Estadual de Santa Cruz; and an

Angiologist at Santa Casa de Itabuna

Author contributions Conception and design: LJOA Analysis and interpretation: LJOA Data collection: LJOA, LSF, PRSM Writing the article: LJOA, LSF, PRSM, MA Critical revision of the article: LJOA, LSF, PRSM, MA Final approval of the article*: LJOA, LSF, PRSM, MA

Statistical analysis: LJOA, PRSM Overall responsibility: LJOA Obtained funding: None.

* All authors have read and approved of the final version of the article submitted to I Vasc Bras. 